\title{
A refuge for threatened sea grasses (Zostera asiatica Miki and Phyllospadix iwatensis Makino) at the islands Iturup and Urup of Kuril archipelago
}

Anton lurmanov ( $\sim$ yurmanov-anton.ya.ru@yandex.ru )

N. V. Tzizin Main Botanical Garden https://orcid.org/0000-0002-0270-8737 Igor Popov

Saint Petersburg University: Sankt-peterburgskij gosudarstvennyj universitet

\section{Research Article}

Keywords: Zostera marina, Zostera asiatica, Phyllospadix iwatensis, seagrass, Iturup, Urup, Kuril Islands

Posted Date: March 29th, 2021

DOl: https://doi.org/10.21203/rs.3.rs-265664/v1

License: (c) (i) This work is licensed under a Creative Commons Attribution 4.0 International License.

Read Full License 


\section{Abstract}

Survey of sea grasses at the coasts of Urup and Iturup islands of Kuril archipelago has been fulfilled. Three species have been found - Zostera marina L., Zostera asiatica Miki and Phyllospadix iwatensis Makino. The last two species are of particular interest as they are threatened and distributed over relatively small area. Unlike the habitats of the main part of their range located at the coasts of Japan and Korea, the habitats of the studied islands do not suffer from anthropogenic pressure. The discovered northern refuge is significant for the sea grasses conservation. Current global warming and increasing anthropogenic pressure on the southern habitat would increase its significance.

\section{Introduction}

Sea grasses is a group of underwater monocotyledonous plants (Monocotylendoneae - Alismatales) widely distributed over coastal waters of all continents except Antarctica (Hogarth, 2015). Their congregations form "underwater meadows" providing an environment for numerous animals and algae; these meadows are especially valuable habitats (Nagelkerken, van der Velde, 2004). Sea grasses are sensitive to anthropogenic influences. Economic activity in the coastal zone increases eutrophication, siltation and turbidity in shallow waters causing decline of the underwater meadows (Duarte 2002; Short et al., 2011; Unsworth et al., 2014). The intentional extermination of sea grasses by humans also occurs as they are used as raw materials for the manufacture of various products. Many species of sea grasses are declining (Orth 2006; Waycott, Williams 2006). This happens especially dramatically in the case of species having a small range. Such species are known for the coastal waters of Japan, Korea and neighboring territories of Russia and China. Phyllospadix iwatensis and Zostera asiatica belong to this category. The first one was assigned to "vulnerable" category of the IUCN red list, the second one - to "near-threatened" but approaching to "vulnerable"; in Japan it is considered "vulnerable" (Short, Waycott, $2010 \mathrm{ab}$ ). The northern parts of the range of these species, i.e. coastal waters of Russia are insufficiently studied. According to the IUCN Sakhalin and Iturup islands are the northeastern extremes of the distribution of Phyllospadix iwatensis, Hokkaido and Sakhalin are the northern extremes of the Zostera asiatica. The specimens from the Kuril Islands northward from Iturup were mentioned in Russian sources, but without details; the last studies in this filed were carried out in 1969 (Ivanova, Tsurpalo, 2017). This information required updating. We have done this work for Urup and Iturup islands. Our hypothesis was that sea grasses are abundant at these islands in contrast to the main part of the range, because, unlike the latter, the islands are poorly developed in terms of economic activity and settlement. Here we present the results of its testing.

\section{Study Area, Methods}

Iturup and Urup islands are ribbon-shaped with uneven edges stretching out from southwest to the northeast. (Figure 1). Iturup is $200 \mathrm{~km}$ long, its width is from 7 to $27 \mathrm{~km}$; Urup is $117 \mathrm{~km}$ long and up to 20 $\mathrm{km}$ wide. Iturup is populated and developed comparing to the other Kuril Islands, but the developed plots occupy a small part of its territory. Only 6500 people live there, while most of the population is 
concentrated in middle of the island. Southern half of the island is considered as protected area; the visits are usually not allowed there. Urup is almost undeveloped and unpopulated (Atlas of the Kuril Islands, 2009). There are two lighthouses located at its southern and northern extremes, where a few people reside. Recently, mining for gold has started on the southern end of the island, and a small shift camp was built. Both islands are distant from mainland; the possibilities for their survey are limited by short expeditions.

In 2019, an expedition for a comprehensive study of the islands was organized. It took place from July 17 to September 25. We took this opportunity to study sea grasses. On both islands we surveyed sections of the coastlines by travelling on foot; doing so, we recorded congregations of sea grasses in the water, visible from the shore, as well as the beached remains. In such a way most of the obtained data concern Phyllospadix iwatensis as it inhabits the shallow waters up to the depths of $4.5 \mathrm{~m}$. The other sea grass species occur deeper; Zostera asiatica inhabits the waters 8-15 $\mathrm{m}$ deep, therefore we could only register their beached remains. We described the specifics of surveyed habitats, including possible sources of negative impacts. The total length of the routes was $55 \mathrm{~km}$ on Iturup and $40 \mathrm{~km}$ on Urup (Fig. 1). The herbarium samples have been collected; the species identification was carried out using the Keys to Plants of the Soviet Far East (Voroshilov, 1982).

\section{Results}

We have found Phyllospadix iwatensis on both islands. It was registered at the coastline growing on various substrates - boulders, sand plots or dense tufa (Figure 2). In some places it formed "meadows", solitary individuals also occurred. The sea grasses growing on tufa had especially big rhizome; it was up to $7 \mathrm{~mm}$ thick; these rhizomes formed dense tussocks. The grasses on sand have not formed such tussocks; they were much thinner; their rhizome was about 1.5 thick. The total length of the coastline where the species was found was $78 \mathrm{~km}$, the length of the line where it was not found was $35 \mathrm{~km}$. If approximately the same ratio of areas with and without this species is typical for the entire coastline of the islands $(858.5 \mathrm{~km})$, then the habitat of this species is about $600 \mathrm{~km}$ of littoral zone. Since the object can live at depths of up to $4.5 \mathrm{~m}$, it is likely that it also lives in other sections of coastal waters.

The other threatened species Zostera asiatica was registered in the only one point located at the western coast of Iturup island. Moreover, we have found Zostera marina in both islands (Unlike the two above mentioned species it is not considered threatened).

No strong negative anthropogenic impacts on sea grasses have been identified. All surveyed areas of the coastline and littoral have been in their natural state. Development in the coastal zone affects an insignificant part of the water area - except for a few small berths, we have not seen any constructions. There was no aquaculture in the coastal area. Any other sources of intensive eutrophication were not found. The main economic activity on Iturup is associated with fishing, which is carried out by trap-nets affecting a little the sea grass habitats. The deposit exploration on Urup, at least at the time of the study, was distant from the coastal zone. 


\section{Discussion}

The revealed habitats of sea grasses on the Kuril Islands are significant for the existence of Phyllospadix iwatensis and, possibly, Zostera asiatica. For both species, a small number of sites of registration are known in the main part of the range, and they are located near the coasts exposed to strong anthropogenic pressure. In our case the habitats occupy a large area and nothing threatens them so far. Economic activity develops slowly and has little effect on sea grasses. The direct extermination of sea grasses is also not expected in a foreseeable future. Sea grasses were harvested in the 1930-1960s in the Russian Far East as a stuff for upholstered furniture and a packaging material (Kulepanov, 2005), as well as for the manufacture of paper and fertilizers (Kardakova, 1953). But now it does not take place. The use of sea grasses is considered in the context of possibilities for extraction of therapeutic and prophylactic substances (Aminina 2005), but large-scale harvesting still does not take place. Although it should be noted that sea grasses are not considered protected in Russia, and they are discussed by scientists in context of the search for potential raw materials, but not as object requiring conservation measures. Therefore, it is possible that the harvesting of sea grasses will be initiated in future.

Marine mammals such as harbor seals Phoca vitulina stejnegeri and sea otters Enhydra lutris occur near the identified sea grass habitats (Kornev et al. 2017). (We also observed them) The presence of marine mammals near sea grasses also partly indicates a good state of habitats, because the animals are even more sensitive to anthropogenic impact. Even the presence of people can scare them away, not to mention a variety of economic activities.

Since the sea grasses were not properly investigated in the past in the area under consideration, we do not know for sure whether they lived there "initially" in large numbers, or they have recently increased in numbers and expanded the range due to climatic changes. The occurrence of Zostera marina is likely to support the assumption of a recent change in sea grass communities, because this species has not been previously recorded, but we found relatively many beached remains on both islands. Anyway the surveyed islands turned out to be a "reserve" for vulnerable species of sea grasses, at least for Phyllospadix iwatensis. The lack of suitable substrates is believed to be the reason for limited distribution of this species. Unlike most of sea grasses it inhabits the specific congregations of rocks. Suitable habitats have a small area for natural reasons, therefore with increase of anthropogenic impact the risk of catastrophic decline is high. In the Chinese part of the range this has already happened (Short and Waycott, 2010a). In our case the habitats occupy a large area. At the same time, it turned out that it grows not only on stones, but also on the sand.

Since the sea grasses occur up to the northernmost extreme of Urup Island, it is likely that they spread further north along the Kurils. Taking into account the current global warming this extension can be relatively large. The boundaries of the ranges of several species are currently shifting northwards (Loarie et al. 2009). It is possible that this also concerns the sea grasses in the Kuril Islands. When discussing the impact of climate warming on sea grasses, the negative impacts drew main attention: overgrowth of algae, increase of eutrophication, increase of frequency of storms that either directly destroy grasses, or 
increase turbidity, etc. (Short, Neckles 1999). However, for northern habitats, the impact of climate warming may be rather positive.

\section{Conclusion}

A refuge for the vulnerable sea grasses species was formed at the southern Kuril Islands. The role of such habitats will increase in the foreseeable future, because in the south of the sea grasses range the anthropogenic pressure is strong, they are undergoing negative changes, in contrast to the north, and at the same time, northern habitats are becoming more favorable for sea grasses due to global warming.

\section{Declarations}

Funding. Field studies and collection of specimens on the Kuril Islands of Iturup and Urup in 2019 were carried out with grant support from the Russian Geographical Society (grant№ 36/2019-I). A. Iurmanov carried out the reported study with the support of RFBR, project number 19-34-90164 and in accordance to Institutional research project № 118021490111-5 at the Unique Scientific Installation Fund Greenhouse.

Conflicts of interest/Competing interests. No conflicts of interests to be declared.

Ethics approval. Field studies have been conducted in accordance with local legislation. The research focused on observation, its impact on environment was insignificant. No protected species or protected areas have been affected.

Consent to participate: consented to participate.

Consent for publication: consented to publish

Availability of data and material. Not applicable. (data transparency)

Code availability. Not applicable.

Authors' contributions. Al and IP participated in the fieldwork, data analysis and writing the manuscript. Both authors read and approved the final manuscript.")

\section{References}

Atlas Kurilskikh ostrovov. (2009). Rossiiskaya Academiia nauk, Vladivostok. [In Russian. Atlas of the Kuril Islands]

Aminina NM (2005) Osnovnye napravleniya issledovaniya moskikh vodorocley i trav Dalnevostochnogo regiona. Isvestiya TINRO 141: 348-354 [In Russian. Main trends of studies of algae and sea grasses in the Far East] 
Duarte CM (2002) The future of seagrass meadows. Environmental Conservation 29: 192-206

Hogarth PJ (2015) The Biology of Mangroves and Seagrasses. $3^{\text {rd }}$ Ed. Oxford etc.: Oxford University Press Ivanova MB, Tsurpalo AP (2017) Soobshestvo Phyllospadix iwatensis na litorali dalnevostoshnikh morey Rossii. Izvestiya TINRO 188: 173-180

Kardakova EA, Kizevetter IV (1953) Morskiye travy Dalnego Vostoka. Primorskoye knizhnoye izdatelstvo, Vladivostok. [In Russian. Sea grasses of Far East]

Kornev SI, Marshuk SP, Danilin DD (2017) Several results of monitoring marine mammals and some species of predator birds on Urup island. In Conservation of biodiversity of Kamchatka and coastal waters: Materials of the XVIII international scientific conference, dedicated to the 70th anniversary of P. A. Khomentovsky's birthday, pp. 447-452. Kamchatpress, Petropavlovsk-Kamchatsky

Kulepanov VN (2005) Issledovaniya macrofitobentosa u poberezhia Primoriya. Izvestiya TINRO 141: 355364

Loarie SR, Duffy PB, Hamilton H, Asner GP, Field CB, Ackerly DD (2009) The velocity of climate change. Nature 462: 1052-1055

Nagelkerken I, Velde G van der (2004) Relative importance of interlinked mangroves and seagrass beds as feeding habitats for juvenile reef fish on a Caribbean island. Marine Ecology Progress Series 274: 153-159

Orth RJ (2006) A Global Crisis for Seagrass Ecosystems. BioScience 56: 987-996

Short FT, Neckles HA (1999) The effects of global climate change on seagrasses. Aquatic Botany 63: 169-196

Short FT, Waycott M (2010a) Phyllospadix iwatensis. The IUCN Red List of Threatened Species 2010: e.T173344A6995596. http://dx.doi.org/10.2305/IUCN.UK.2010-3.RLTS.T173344A6995596.en

Short FT, Waycott M (2010b) Zostera asiatica. The IUCN Red List of Threatened Species 2010: e.T173339A6994461. http://dx.doi.org/10.2305/IUCN.UK.2010-3.RLTS.T173339A6994461.en

Short FT, Polidoro B, Livingstone SR, Carpenter KE, Bandeira S, Bujang JS, Calumpong HP, Carruthers TJB, Coles RG, Dennison WC, Erftemeijer PLA, Fortes MD, Freeman AS, Jagtap TG, Kamal AHM, Kendrick GA, Kenworthy WJ, La Nafie YA, Nasution IM, Orth RJ, Prathep A, Sanciangco JC, van Tussenbroek B, Vergara SG, Waycott M, Zieman JC (2011) Extinction risk assessment of the world's seagrass species. Biological Conservation 144:1961-71

Unsworth RKF, Keulen van M, Coles RG (2014) Seagrass meadows in a globally changing environment. Marine Pollution Bulletin 83: 383-386 
Voroshilov VN (1982) Opredelitel rasteniy sovetskogo Dalnego Vostoka. Nauka, Moscow [In Russian. Keys to Plants of the Soviet Far East]

Waycott M, Williams SL (2006) A global crisis for seagrass ecosystems. Bioscience 56: 987-996

\section{Figures}

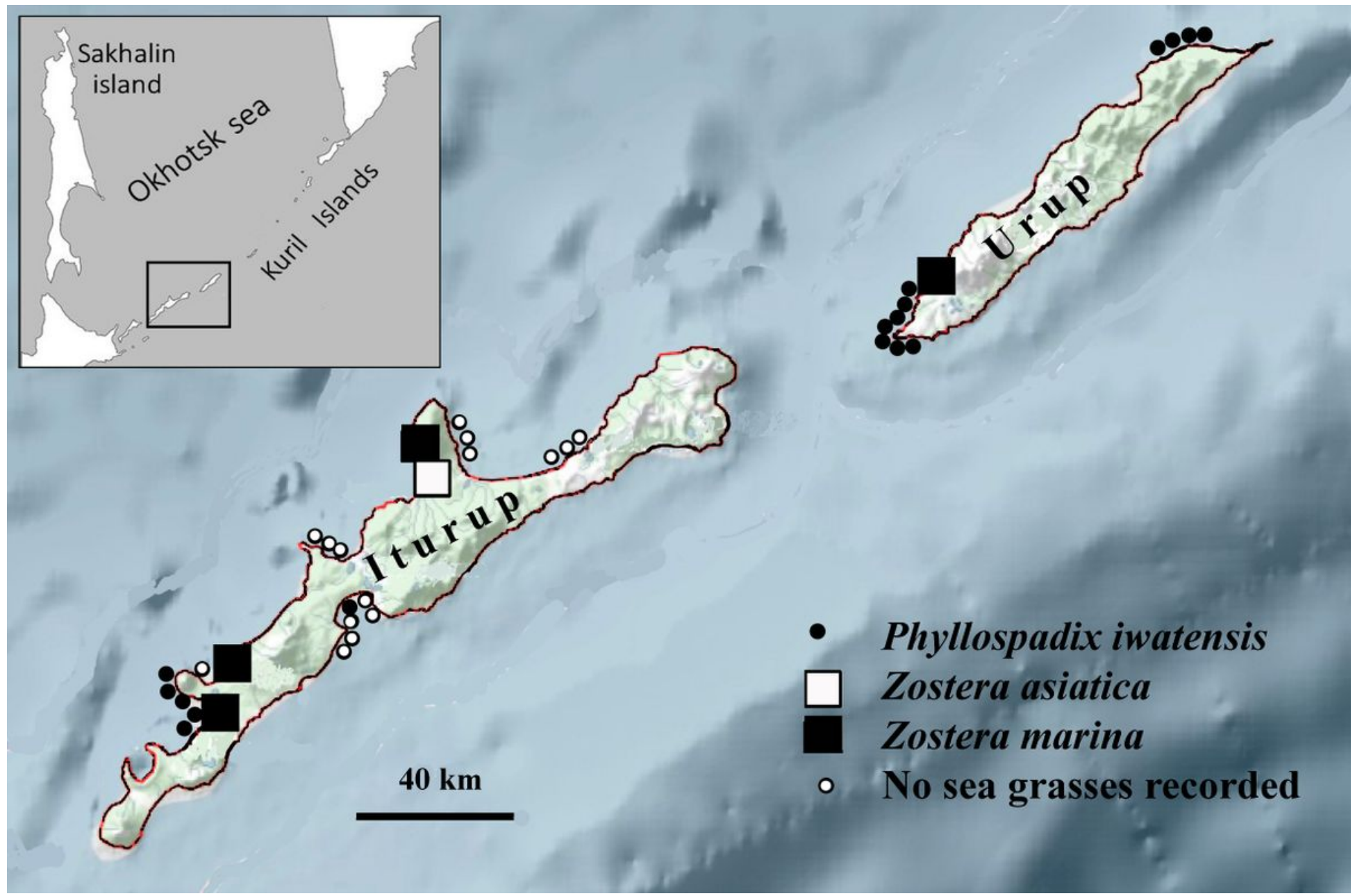

\section{Figure 1}

Study area and the locations of sea grasses records. Note: The designations employed and the presentation of the material on this map do not imply the expression of any opinion whatsoever on the part of Research Square concerning the legal status of any country, territory, city or area or of its authorities, or concerning the delimitation of its frontiers or boundaries. This map has been provided by the authors. 


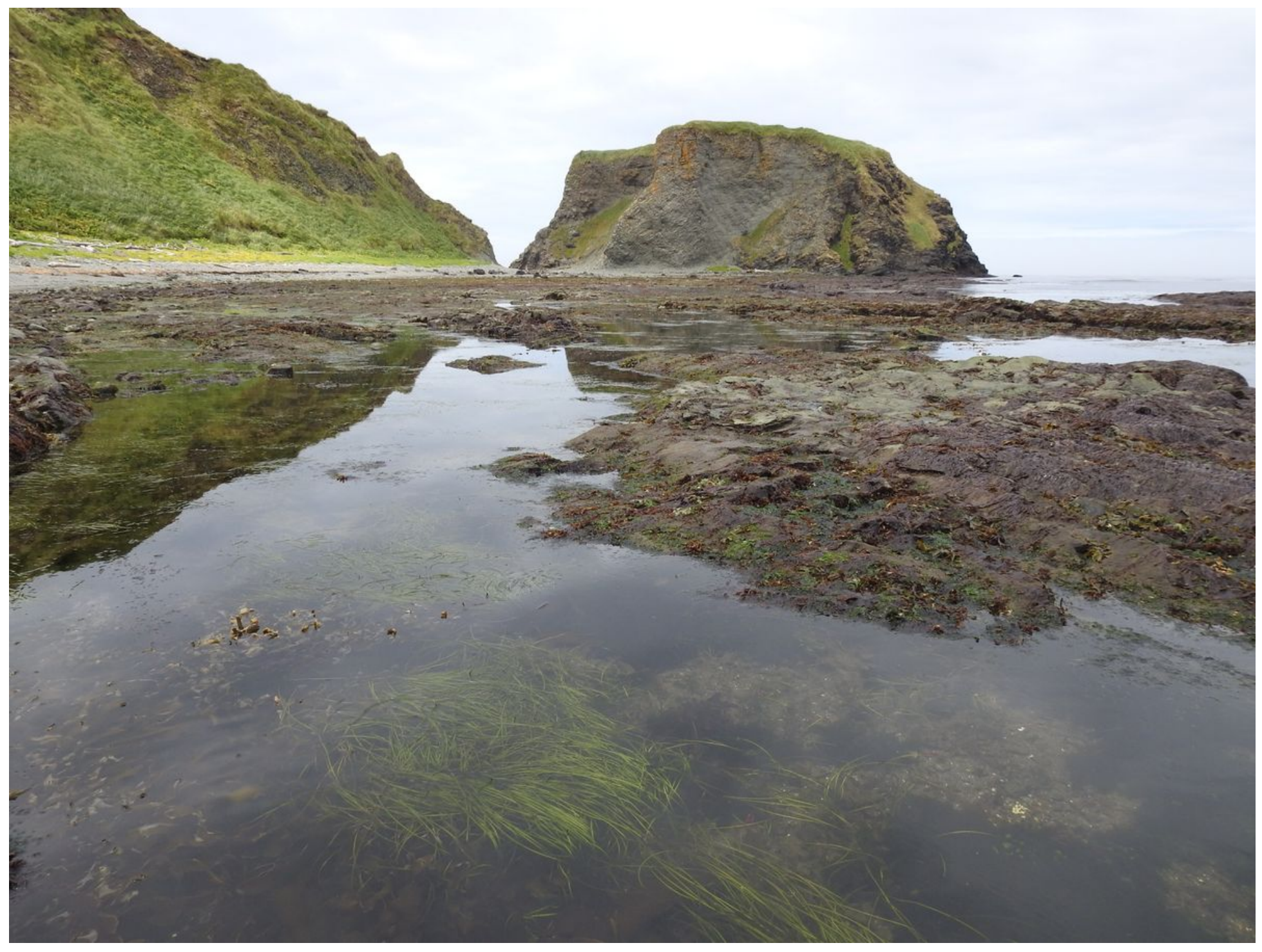

Figure 2

Phyllospadix iwatensis in the northern section of Urup island. 